University of Nebraska - Lincoln

DigitalCommons@University of Nebraska - Lincoln

U.S. Environmental Protection Agency Papers

U.S. Environmental Protection Agency

2008

In Focus: Award Symposium for Dr Gerry Brooks at the ACS 233rd National Meeting, Chicago, March 24-29, 2007

Derek W. Gammon

U.S. Environmental Protection Agency

Follow this and additional works at: https://digitalcommons.unl.edu/usepapapers

Gammon, Derek W., "In Focus: Award Symposium for Dr Gerry Brooks at the ACS 233rd National Meeting, Chicago, March 24-29, 2007" (2008). U.S. Environmental Protection Agency Papers. 121.

https://digitalcommons.unl.edu/usepapapers/121

This Article is brought to you for free and open access by the U.S. Environmental Protection Agency at DigitalCommons@University of Nebraska - Lincoln. It has been accepted for inclusion in U.S. Environmental Protection Agency Papers by an authorized administrator of DigitalCommons@University of Nebraska - Lincoln. 


\section{In Focus: Award Symposium for Dr Gerry Brooks at the ACS 233rd National Meeting, Chicago, March 24-29, 2007}

A symposium in honor of Dr Gerry Brooks winning the International Award for Research in Agrochemicals was organized by me, D Gammon, with help from $\mathrm{RD}$ Wauchope. The award is the highest given by the AGRO Division (formerly Agrochemicals Division) of the ACS. The symposium lasted a full day and consisted of an introduction, a lecture by Gerry and nine subsequent lectures. The high caliber of the recipient can be judged by the fact that five of the nine speakers were previous winners of the award (B Hammock, J Clark, R Krieger, H Ohkawa and E Hodgson) and another is to be the 2008 winner (D Soderland).

In my introduction, I pointed out that Gerry had served as the Editor-in-Chief of Pest Management Science (formerly Pesticide Science) for the past 17 years. He started his career as an organic chemist and was the first person to synthesize ${ }^{14} \mathrm{C}$ labeled cyclodiene insecticides (1957-1959). He showed that their metabolism involved the formation of an epoxide, and was then the first to demonstrate the existence of an epoxide hydrolase (EH) in insects and mammals. At PIL Slough, UK in 1965-67 and at the University of Sussex, UK, colleagues were among the first to show the existence of CYP450s in insects. Insecticide resistance mechanisms were clarified and found to involve increased metabolism. Returning to epoxide hydrolase, Gerry showed that it also played a key role in juvenile hormone $(\mathrm{JH})$ metabolism in insects. He developed a number of inhibitors of epoxide hydrolase and also played a key role in defining the mechanism of action of the $\mathrm{JH}$ antagonist, precocene. This insecticide causes the destruction of the corpora allata, the site of $\mathrm{JH}$ biosynthesis.

The first paper after Gerry's was delivered by B Hammock (UC Davis). The title of his lecture, "Gerry Brooks' epoxide hydrolase: thirty five years to a pharmaceutical" set the stage for many of the following papers. Hammock's group, which now includes a spin-off company in California, is developing drug candidates for the treatment of several conditions. These include hypertension/stroke, pain management and inflammation. J Clark (University $\mathrm{MA}$, Amherst) presented some interesting findings on the effects of pyrethroids on nerve Ca channels and the international flavor of the meeting was then exemplified by a talk by R ffrench-Constant (University of Exeter, UK) on cyclodiene resistance mechanisms in insects, at the molecular level of the GABA receptor and DDT. The molecular biology of insect P450 genes was then described by R Feyereisen (University of Nice, France) and an example of both induction and inhibition of insect P450 oxygenases by the synergist piperonyl butoxide was described by R Krieger (UC Riverside). Pyrethroid resistance in insects was described at the level of the Na channel by D Soderland (Cornell University, NY). The next talk was given by J Bloomquist (Virginia Tech, VA), and we were then presented with a paper by H Ohkawa (Fukuyama University, Japan) on the use of molecular biology as a source of probes suitable for environmental monitoring for cyclodienes and other POPs. The concluding presentation, which was delivered by E Hodgson (NC State University, NC), was on enzyme induction/inhibition by pesticides in human hepatocytes.

In this special In Focus section, we include a selection of the papers presented at the symposium. As editor, I would like to thank all the contributors and to congratulate Gerry Brooks again on his well-deserved achievement in winning this award, which reflects the esteem with which he is held in the pesticide/agrochemical world.

Dr Derek W Gammon Pesticide Regulation, California EPA, Sacramento, CA, USA 